\title{
HOW MODERN IS IT? RUCHOME OBRAZY AMERYKI WE WCZESNYM KINIE NIEMIECKIM ${ }^{1}$
}

W styczniu 1914 roku Erich Schlaikjer opublikował artykuł zatytułowany Amerikanismus, który stanowił podsumowanie raczej typowych dla tamtych czasów postaw, a jednocześnie zapowiadał późniejszą krytykę, znanej dobrze do dziś, „amerykańskiej inwazji”. Autor ubolewał nad schyłkiem kulturowej tradycji, będącym efektem „barbarzyńskich” wpływów zajmująco przez niego opisanego amerykanizmu. Po odniesieniu się do drapaczy chmur jako symbolu braku tradycji Ameryki, a także do niedorzecznego wzrostu ilości kosztem estetycznej jakości jako ogólnie amerykańskiej cechy, autor kontynuował relacjonowanie najnowszej, nadmiernej żądzy zysku w Berlinie:

Jeśli niemiecki właściciel pubu umieści karuzelę w swoim ogrodzie, nie będzie to przejaw amerykańskiego zachowania. Jednak, jeśli bogata berlińska gazeta zamontuje siedemdziesiąt pięć karuzeli na pustym polu w Marchii Brandenburskiej; jeśli tę scenę grozy lączy z Berlinem specjalny pociąg, a prenumeratorom tegoż czasopisma przysługuje darmowy transport i gorący posiłek - to jest to klasyczny przykład amerykanizmu w Niemczech ${ }^{2}$.

Ta „scena grozy” przypomina parki rozrywki, które na przełomie wieków powstawały nie tylko w amerykańskich miastach. Berlin miał swój lunapark wzorowany na Coney Island już w 1904 roku$^{3}$. Niemniej jednak dla Schlaikjera

1 Tekst przedstawiony na sympozjum American Mass Culture in Europe, które odbyło się w Netherlands Institute for Advanced Study (NIAS) w Wassenaar, 24 stycznia 1992 roku.

2 E. Schlaikjer, Amerikanismus, „Kunstwart und Kulturwart” 1914, Bd. XXVII, H. 8, s. $102-104$.

3 Na temat pojawienia się i o społecznych funkcjach amerykańskich parków rozrywki zob. J. Kasson, Amusing the Million: Coney Island at the Turn of Century, Hill and Wang: New York 1978. Lunapark Terrasen am Halensee otwarty w 1904 r. na Kurfürstendamm w Berlinie.

Por. H. Lethen, Chicago und Moskau, Berlins moderne Kultur der 20er Jahre zwischen Inflation und Weltwirtschaftskirse, [w: ] Die Metropole: Industriekultur in Berlin im 20. Jahrhundert, Bd. II, Hrsg. J. Boberg, T. Fichter, E. Gillen, Beck: München 1986, s. 190-213, cytat ze s. 202. 
„mięsista atrakcyjność” („raw attractions”) sztuk scenicznych wywodziła się z Ameryki, gdzie - jak doniesiono - sekretarz stanu pojawił się niedawno na scenie varieté. Wreszcie, degradowanie wartościowego dzieła sztuki przez przemysł filmowy przyciągający widzów nazwiskiem słynnego twórcy również zostało uznane za strategię amerykańską. Prawdopodobnie był to przytyk do ważnego wydarzenia filmowego roku 1913, premiery filmu Atlantis - kosztownej produkcji duńskiej wytwórni Nordisk. Film, będący adaptacją powieści Gerharta Hauptmanna, opowiada o niemieckim rozbitku, który w drodze do Ameryki poszukuje samego siebie. Schlaikjer nie miał wątpliwości: „Cała kinematografia w ogóle ma w sobie coś amerykańskiego"4.

Zatem nawet przed I wojną światową Ameryka była uznawana przez niektórych za ojczyznę nowej kultury masowej czy też „barbarzyństwa”, które było wówczas bliskie opanowania całego świata. W istocie, dysputa o amerykanizacji Europy liczy sobie cały wiek i towarzyszyła Stanom Zjednoczonym w procesie stawania się światową potęgą gospodarczą. William T. Stead, brytyjski publicysta, który doceniał animusz Ameryki oraz popierał zjednoczenie ludności mówiącej w języku angielskim, w stworzonym w 1902 roku pamflecie, zatytułowanym The Americanization of the World or The Trend of the Twentieth Century, pisze:

Centrum oporu wobec amerykańskich zasad znajduje się w Berlinie, natomiast czołowym zwolennikiem, a jednocześnie przeciwnikiem amerykanizacji jest Cesarz Niemiec. Jest coś daremnego w heroicznej postawie władcy Niemiec, wzbraniającego się przed amerykańską powodzią. [...] Przez cały czas piasek, na którym stoi cesarz, przesiąka wodą, podmywającą fundamenty, w których zakorzenily się stopy, więc mimo odżegnywania się od amerykanizującego wpływu, jest on osobiście nań podatny. W Europie nie znajdziemy bardziej zamerykanizowanych miast niż Berlin i Hamburg. Są one amerykańskie w gwałtownym rozwoju, są amerykańskie w swym impecie, są amerykańskie $\mathrm{w}$ prędkim wprowadzaniu udogodnień dla szybkiego transportu [...] Niemiecki fabrykant, niemiecki konstruktor statków, niemiecki inżynier, wszystkim śpieszno do nabycia i używania najnowszych amerykańskich automatów. Amerykańska maszyna do pisania jest wiodącą zarówno w Niemczech,

${ }^{4}$ E. Schlaikjer, s. 104. Erich Schlaikjer opublikował później zbiór esejów: Im Kampf mit der Schande: Gesammelte Aufsatze aus dunkler Zeit, Verlag der Taglichen Rundschau: Berlin 1920. Po przegranej wojnie Schlaikjer bronił swych nacjonalistycznych i konserwatywnych poglądów na rzecz Alldeutschen (najprawdopodobniej autorka ma na myśli Ligę Pangermańską, niem. Alldeutscher Verband, niemiecką organizację nacjonalistyczną - przyp. tłum.). Dziennikiem, którego szczególnie nienawidził za „pacyfistyczne” i „liberalne” nastawienie oraz za redaktora naczelnego żydowskiego pochodzenia, był „Berliner Tageblatt”. Prawdopodobnie pisząc o „klasycznym przypadku amerykanizmu”, odnosił się do kampanii reklamowej tej gazety. 
jak i w Wielkiej Brytanii. Co istotniejsze, amerykański farmer zwiększa ilość wyrabianego chleba i bekonu, które trafią później na niemieckie stołys.

Film uchodził za dominujące narzędzie „amerykanizacji”. Choć kinematografia zrodziła się jednocześnie w kilku różnych krajach - pierwsze pokazy filmowe w Niemczech, Francji czy Stanach Zjednoczonych odbyły się w 1895 roku - samo medium zaczęto szybko utożsamiać z Ameryką, a Thomas Alva Edison został zapamiętany jako legendarny ojciec ruchomych obrazów. Nowe badania dowiodły, iż mit hollywoodzkiej hegemonii nie zawsze był potwierdzony danymi empirycznymi ${ }^{6}$. Mimo to ufność w globalną dominację amerykańskiej kultury masowej, formującej się u zarania kinematografii, a utrwalającej przez całe stulecie, jest nadal kluczowa dla naszego dzisiejszego odbioru kina amerykańskiego. Na przykład znacząca część produkcji „Nowego Kina Niemieckiego” została zrealizowana w toku nieustannej utarczki z wszechobecną wizją amerykańską. W filmie drogi Z biegiem czasu (Im Lauf der Zeit, 1976) Wima Wendersa jeden z jego bohaterów mówi: „Jankesi skolonizowali naszą nieświadomość”. Jak to wszystko się zaczęło? Kiedy po raz pierwszy amerykańskie filmy wkroczyły do niemieckich kin oraz do niemieckiej świadomości kulturowej? Jak wówczas postrzegano amerykański film i jak o nim dyskutowano?

Powstaniu kina w Niemczech towarzyszyły różnorodne refleksje o proweniencji literackiej. W nowej, oferowanej przez kino (Kintopp) rozrywce pisarze upatrywali zarówno zagrożenia, jak i wyzwania. Prawdopodobnie w żadnym innym kraju kwestia statusu filmu jako dzieła sztuki nie sprowokowała aż tak wzmożonej dyskusji. Na zasięg sporu Kino-Debatte, którego najbardziej żywotny okres przypada na pierwszą dekadę XX wieku, wskazało kilka zbiorów tekstów ${ }^{7}$.

${ }^{5}$ William T. Stead, The Americanization of the World or the Trend of the Twentieth Century, Gerland Pub. Inc.: New York-London 1972 (reprint wersji z 1902 roku). Również w Niemczech, od około 1902 roku, ekonomiczna ekspansja Ameryki była postrzegana jako groźba. Książka Reinera Pommerina, Der Kaiser und Amerika: Die USA in der Politik der Reichsleitung 1890-1917, Böhlau Verlag: Köln/Wien 1986, dostarcza refleksji na temat wczesnych tekstów o Die amerikanische Gefahr, s. 207-220. W kontekście badań na temat niemieckich zastosowań „amerykanizmu“ por. Theodor Lüddecke, Amerikanismus als Schlagwort und Tatsache, „Deutsche Rundschau“ 1930 (März), Bd. 222, s. 214-221; Otto Basler, Amerikanismus: Geschichte des Schlagwortes, „Deutsche Rundschau“ 1930 (August), Bd. 224, s. 142-146.

${ }^{6}$ Zob. Joseph Garncarz poniżej.

7 Szczególnie Jörg Schweinitz, Hrsg., Prolog vor dem Film: Nachdenken über ein neues Medium 1909-1914, Reclam: Leipzig 1992; Anton Kaes, Hrsg., Kino-Debatte: Texte zum Verhältnis von Literatur und Film 1909-1929, Niemeyer: Tübingen 1978; Fritz Güttinger, Hrsg, Kein Tag ohne Kino: Schritseller über den Stummfilm, Deutsches Filmmuseum: Frankfurt a.M. 1984. Hätte ich das Kino! Die Schriftseller und der Stummfilm, 
Więcej źródeł można znaleźć w czasopismach filmowych, periodykach literackich, a nawet $w$ ówczesnej beletrystyce. Piśmiennictwo rozwijające się wraz z rosnącym w siłę nowym medium przyczyniło się do zaistnienia dyskursu, $w$ ramach którego kino jako instytucja kulturalna zyskało na znaczeniu. Jako że do dziś przetrwał jedynie niewielki ułamek filmów z epoki kina niemego, zaś te, które ocalały, są trudno dostępne, współcześnie powinno dążyć się do rekonstrukcji ówczesnego krajobrazu kulturowego. Pozostaje oczywiście pytanie, czy wspomniane dokumenty dotyczące recepcji są reprezentatywne dla szerokiej widowni? Czy milczące masy, w szczególności kobiety, miały inne upodobania niż intelektualiści i literaci?

Niemieckie reakcje na wczesne kino często bywały przeplatane utopijną bądź dystopijną projekcją Ameryki. Filmy powstające w Stanach Zjednoczonych w fascynująco natychmiastowy sposób transmitowaty odbicia Ameryki, które uchodziły za bardziej "autentyczne” od dotychczas proponowanych przez prasę. W tym samym czasie bieżące teksty traktujące o amerykańskim stylu życia tworzyły kontekst percypowania tych nowych obrazów. Poprzez polityczne spektrum Ameryka służyła jako wysoce ambiwalentny symbol łączący fascynację i lęk spowodowane gwałtowną modernizacją dokonującą się po obu stronach Atlantyku. Wiele elementów fundamentalnych dla niemieckiego postrzegania Ameryki jako wzorca nowoczesności oraz stosownego porozumienia hierarchii kulturowych broni się po dziś dzień. Poglądy te ukształtowały się na początku $\mathrm{XX}$ wieku, gdy rodził się film: nowe medium kultury masowej. Podczas gdy Schreckbild Amerika tłumaczyło wszystko, co dla konserwatywnej krytyki było odpychające we wschodzącej kulturze masowej, identyfikowanie filmu z Ameryką było wykorzystywane także w pozytywny sposób. W 1913 roku dramaturg Walter Hasenclever napisał apologię Kintoppu. Niemiecki pisarz przekonywał, iż nawet nieprzychylne rozpatrzenie kina $w$ kategoriach tradycyjnej sztuki nie wpływa na jego wartość:

Kintopp pozostaje amerykański, pomysłowy i kiczowaty zarazem. Temu właśnie zawdzięcza swoją popularność i sukces. I żadna ustawa Reichstagu nie wplynie negatywnie na dochodowość Kintoppu, ponieważ jego nowoczesność polega na umiejętności zadowolenia zarówno idiotów, jak i mózgowców zgodnie z ich psychologiczną naturą9

Klett, Stuttgart 1976, katalog wystawy w Schiller-Nationalmuseum, Marbach nad Neckar, zawiera również obszerną liczbę dokumentów na temat wczesnego kina.

${ }^{8}$ Podejście zaproponowane również przez Miriam Hansen w Early Silent Cinema: Whose Public Sphere?, „New German Critique” 1983, Spring/Summer, No. 29, s. 147-184.

9 Walter Hasenclever, Der Kintopp als Erzieher, Eine Apologie, [w:] Kino-Debatte, s. 47-49. Tłumaczenie własne autorki. 
W amerykańskim filmie podziwiano rzeczowy i zwięzły styl narracji. W 1911 roku Karl Hans Strobl, autor powieści przygodowych, określił kino jako „teatr na najwyższych obrotach”, do którego to przystawała „amerykańska reguła instant”. „Niecierpliwy, nerwowy krok” nowej sztuki, która była niczym „automat z napojami wzrokowej przyjemności”, dopasował się idealnie do „naszego życia pełnego napięć, w końcu każdy wie, jak trudno wytrwać do końca Wagnerowskiej opery po całym dniu pracy"10.

Sceny przedstawiane $\mathrm{w}$ filmach niekoniecznie były aż tak nowoczesne. Oczywiście, na przykład około 1903 roku wśród produkcji Edison Manufacturing Company zdarzały się „aktualności”, krótkie filmy dokumentalne obrazujące nowoczesne, wielkomiejskie sceny, jak na przykład korek uliczny w Nowym Jorku, widoki na Coney Island, budowa wieżowców i metra czy nowe szybkie środki transportu: samoloty, pociągi, samochody ${ }^{11}$. Ameryka była przedstawiana jako ojczyzna postępu technicznego nie tylko w filmach dokumentalnych, ale także w gatunku science fiction. Dobrym tego przykładem jest ciepło przyjęta powieść autorstwa Bernharda Kellermana pod tytułem Tunel (Der Tunnel), opublikowana w 1913 roku i sfilmowana na przełomie 1914 i 1915 roku, która była niejako zapowiedzią Metropolis (1927) Fritza Langa. Jednakże gatunkiem powszechnie uznanym za typowo amerykański, odnoszącym największe sukcesy wśród publiczności, był western. Wiele dawnych mitów dotyczących surowego życia na Zachodzie doczekało się wdzięcznego odrodzenia w kinie. Niczym awers i rewers Amerykę wytyczały pełne drapaczy chmur metropolie z jednej strony oraz legendarny Far West z drugiej. Nierzadko jedna ze stron była postrzegana poprzez pryzmat drugiej ${ }^{12}$. Nakładanie na siebie nowoczesnych i archaicznych scenariuszy było charakterystyczne dla niemieckich wyobrażeń na temat Ameryki. Zjawisko to było szczególnie zauważalne w popularności postaci kowboja, klasycznej amerykańskiej ikony. Jako jedna z „wielkich osobowości”, wytwór współczesnej kultury masowej, swoją archaiczną siłą i wolnością wyznaczył elementarne cechy nowoczesnej męskości znanej do dziś nie tylko z reklam Marlboro.

${ }^{10}$ Karl Hans Strobl, Der Kinematograph, [w: ] Kein Tag ohne Kino, s. 52.

11 Kemp Niver, Early Motion Pictures: The Paper Print Collection in the Library of Congress, Library of Congress: Washington 1985, zawiera duży zbiór wczesnych dokumentów wraz z opisami i ilustracjami.

12 Beeke Sell Tower, Asphaltcowboys and Stadtindianer: Imaging the Far West, [w: ] Envisioning America: Prints, Drawings and Photographs by George Grosz and his Contemporaries 1915-1933, Harvard University, Busch-Reisinger Museum, 1990, s. 17. Katalog ten jest bardzo interesującym źródłem utopijnych i dystopijnych odczytań Ameryki $\mathrm{w}$ ramach niemieckiego dyskursu modernizacji wraz z towarzyszącymi mu artystycznymi odtworzeniami tego złożonego obrazu. 
Western był jednym z pierwszych gatunków w historii kina ${ }^{13}$. Na początku XX wieku amerykański Zachód był romantyzowany przez przedstawicieli „młodego Wschodu": Theodore'a Roosevelta, malarza Frederica Remingtona oraz Owena Wistera, autora Wirgińczyka (The Virginian, 1902) pierwszej modelowej powieści o Dzikim Zachodzie ${ }^{14}$. Prawie w tym samym czasie Edwin S. Porter wyreżyserował dla studia Edisona Napad na ekspres (The Great Train Robbery, 1903), który ustalił klasyczny schemat westernu oparty na przestępstwie, pościgu i wy$\mathrm{roku}^{15}$. Ten pierwszy film fabularny traktujący o Dzikim Zachodzie Lewis Jacobs określił mianem „biblii każdego reżysera” - obraz Portera wprowadził bowiem nową technikę montażu równoległego ${ }^{16}$. Przez najbliższe lata Napad na ekspres odnosił niepowtarzalny sukces w nickelodeonach, a także doczekał się szeregu remakeów. W Niemczech wyświetlany był pod tytułami: Der große Zugüberfall czy Der Überfall auf einen amerikanischen Expresszug. Począwszy od 1894 roku Edison Manufacturing Company doczekało się przedstawicielstwa w Europie, najpierw w Londynie, a z 1906 rokiem - także w Berlinie.

Gilbert M. Anderson alias Broncho Billy (właściwie Max H. Aronson, 1882-1971*) zagrał w Napadzie na ekspres jedną ze swoich pierwszych ról - zastrzelonego przez bandy tów pasażera. W 1907 roku wraz z Georgem K. Spoorem założył wytwórnię Essanay, a następnie stworzył postać gruboskórnego kowboja, Broncho Billy'ego, która przez siedem lat pojawiła się w serii przeszło trzystu pięćdziesięciu filmów ${ }^{17}$. Nazwisko bohatera pojawiało się w tytule każdego filmu jako swoisty znak firmowy. Stał się on gwiazdą jeszcze zanim przemysł filmowy ustanowił „system gwiazd”. W Kalifornii zespół Andersona produkował w przybliżeniu jeden film tygodniowo. Powstające wówczas obrazy nie tworzyły wspólnie serii z ciągłością fabularną, każdy film stanowił niezależną historię $\mathrm{w}$ formie krótkiego metrażu. Broncho Billy wcielał się w różne role. Czasem był czarnym charakterem, czasem szeryfem, a najczęściej dwoistym, szorstkim typem o go-

13 Zob. Peter Stanfield, The Western 1909-14: A Cast of Villains, [w: ] Film History, Vol. I, 1987, s. 97-112. Również Jon Tuska, The Filming of the West, Doubleday, Garden City: New York 1976.

14 Zob. G. Edward White, The Eastern Establishment and the Western Experience: The West of Frederic Remington, Theodore Roosevelt, and Owen Wister, Yale UP: New Haven 1968.

15 Zob. Charles Musser, Before the Nickelodeon: Edwin S. Porter and the Edison Manufacturing Company, California UP: Berkeley-Los Angeles/Oxford 1991.

16 Lewis Jacobs, The Rise of the American Film, Harcourt, Brace and Co.: New York 1939, s. 43. Zob. również Charles Musser, The Emergence of Cinema: The American Screen to 1907 (History of the American Cinema, Vol. I), California UP: Berkeley-Los AngelesLondon 1990, The Transition to Story Films: 1903-1904, s. 337-369.

17 Dla filmografii zob. ed. Edward Buscombe, The BFI Companion to the Western, André Deutsch/BFI: London 1988. 
łębim sercu - archetyp ten w przyszłości rozwijać będą William S. Hart i inni ekranowi kowboje. Wiele filmów z Broncho Billym wyświetlanych było również w Niemczech: w 1911 roku Essanay założył swoją filię w Berlinie. Jednakże cenzura i dystrybucja w tamtych czasach często działała niekonsekwentnie w różnych miastach.

Zanim jednak pójdziemy dalej w rozważaniach nad rolą kowboja w niemieckiej kulturze, należy wspomnieć o kilku podstawowych informacjach na temat obiegu amerykańskich filmów w Niemczech w epoce kina niemego. Przed I wojną światową Niemcy głównie importowały filmy z zagranicy. Jak wykazały badania Kristin Thompson na temat dystrybucji filmowej w latach 1912-1913 - w okresie, gdy środowiska literackie odkrywały kino - około 30 procent dramatów pokazywanych w Niemczech pochodziło ze Stanów Zjednoczonych. Amerykański przemysł filmowy zajmował zatem czołową pozycję w eksporcie filmów, pozostawiając w tyle między innymi Francję czy Włochy ${ }^{18}$. Prekursorskie badania Emilie Altenloh poświęcone socjologii widowni potwierdzają te informacje ${ }^{19}$.

Wybuch I wojny światowej spowodował zamknięcia rynku krajowego. Import zagranicznych filmów znacznie się zmniejszył, choć nigdy nie upadł całkowicie. Już w 1914 roku, po wybuchu wojny, naczelnictwo berlińskiej policji wprowadziło rozporządzenie o dostosowaniu wszelkich wydarzeń i seansów filmowych do wagi ówczesnej sytuacji. W listopadzie 1914 roku organizacja na rzecz ochrony kinematografii, Verein zur Wahrung der Interessen der Kinematographie und verwandter Branchen, doradziła właścicielom kin, aby podczas wojny nie wyświetlali ani filmów pochodzących z wrogich krajów, ani tych zrealizowanych w wytwórniach, których kapitał pochodził z państw nieprzyjaznych. Niemiecki przemysł filmowy dostrzegł w tej sytuacji szansę zwiększenia produkcji oraz stanowczego zaznaczenia swojego miejsca na rynku filmowym. Wraz z początkiem wojny nastąpił boom tematów nacjonalistycznych. W styczniu 1915 roku, na mocy ustawy Bundesratu, filie zagranicznych wytwórni zostały przejęte przez niemiecką administrację. Jednakże filmy zagraniczne nadal trafiały do Niemiec drogą przez kraje neutralne, takie jak Dania czy Holandia. Zapisy cenzury wykazują, że amerykańskie filmy produkowane przez wytwórnie Kalem, American Biograph, Selig, Tannhouser czy Independent Motion Picture Company Carla Laemmle w dalszym ciągu wchodziły do niemieckiej dystrybucji, jako że Stany Zjednoczone aż do 1917 roku były państwem neutralnym ${ }^{20}$. Niemniej,

18 Kristin Thompson, Exporting Entertainment: America in the World Film Market 1907-34, BFI: London 1985, s. 37.

19 Emilie Altenloh, Zur Soziologie des Kino: Die Kino-Unternehmung und die sozialen Schichten ihrer Besucher, Eugen Diederichs: Jena 1914, s.10.

20 Zob. Herbert Birett, Verzeichnis in Deutschland gelaufener Filme: Entscheidungen der Filmzensur 1911-1920, Saur: Berlin-Hamburg-München-Stuttgart 1980. 
zakaz mocno skomplikował ówczesny import. Ostatecznie więc niemiecki przemysł filmowy zyskał na wybuchu wojny. Musiało też minąć kilka lat, aby waluta mogła się odrodzić i reaktywować import zagranicznych filmów.

18 grudnia 1917 roku, z inicjatywy Ericha Ludendorffa i dzięki kapitałowi dwudziestu pięciu milionów reichsmarek, powstała wytwórnia Universum-Film AG (w skrócie UFA) ${ }^{21}$. Powojenna sytuacja gospodarcza oraz wysoka wartość dolara amerykańskiego oznaczały, że już w połowie lat 20. kino USA ponownie podbiło ziemie niemieckie. Przed 1925 rokiem UFA popadła w kryzys finansowy i była zmuszona do nawiązania współpracy z Paramountem i MGM. Skutkiem tego co drugi film wyświetlany w kinach UFA pochodził z Hollywood. Powódź przeciętnych amerykańskich obrazów wzbudziła oburzenie nawet wśród niemieckich krytyków niepodzielających nacjonalistycznych poglądów. W 1926 roku Herbert Jhering, lewicowy krytyk filmowy i teatralny, pisal:

Liczba ludzi oglądających filmy, ale nieczytających żadnych książek, sięga już milionów. Wszyscy oni są podporządkowani amerykańskiemu gustowi, wszyscy są ujednoliceni i zunifikowani [...]. Amerykański film to nowy, rozwijający się, światowy militaryzm. Jest groźniejszy niż pruskie wojska. Nie pochłania on pojedynczej indywidualności, pochłania Völkerindividuen (indywidualność zbiorową) ${ }^{22}$.

Twórczość Davida Warka Griffitha stanowi dobry przykład zakłócenia spowodowanego wojną. W okresie pracy w wytwórni Biograph (1908-1914) Griffith wyprodukował około czterystu pięćdziesięciu filmów. Jak podają zapisy cenzorskie, wiele z nagranych na kilku rolkach taśmy wczesnych westernów takich jak Leather Stocking (1911), Telegrafistka $z$ Lonedale (The Lonedale Operator, 1911), The Last Drop of Water (1911), The Battle at Elderbush Gulch (1913) oraz dramatów społecznych podobnych do Muszkieterów z Pig Alley (The Musketeers of Pig Alley, 1912) odniosło sukces w Niemczech. Częstym problemem jest rozpoznanie filmu po tytule, ponieważ cenzura pozostawiała jedynie tytuł niemiecki, pomijając oryginalny ${ }^{23}$. W tym samym czasie filmy w różnych miastach Niemiec poddawane były wstępnej cenzurze ze strony funkcjonariuszy policji, którzy często dochodzili

21 Dla szczegółowego raportu historii UFA zob. Hans-Michael Bock, Michael Töteberg (Hrsg.), Das Ufa-Bunch, Zweiausendeins: Frankfurt a.M. 1992, oraz Klaus Kreimeier, Die Ufa-Story: Geschichte eines Filmkonzerns, Hanser: München-Wien 1992.

${ }^{22}$ Herbert Jhering, UFA und Buster Keaton, [w:] Von Reinhardt bis Brecht, Bd. II, Berlin 1961, s. 509. Tłumaczenie własne autorki.

23 Herbert Birett, Das Filmangebot in Deutschland 1895-1911, Winterberg: München 1991, podaje 109 filmów autorstwa Davida Warka Griffitha. Zob. również Helmut H. Diederichs, Frügheschichte deutscher Filmtheorie: Ihre Entstehung und Entwicklung bis zum Ersten Weltkrieg, Załącznik: Griffith'Biograph-Filme in Deutschland, [praca doktorska], Universität Münster, 1991, s. 626-631. 
do odmiennych wniosków. Należałoby przeprowadzić skomplikowane badania, aby móc odpowiedzieć, czy, kiedy i gdzie filmy te były rzeczywiście wyświetlane i które sceny musiały zostać wycięte. Producenci ze Stanów Zjednoczonych byli oczywiście zainteresowani zaspokojeniem potrzeb niemieckiego rynku. W archiwach wytwórni Biograph z 1908 roku, przechowywanych w Muzeum Sztuki Nowoczesnej w Nowym Jorku, nadal można znaleźć karty z niemieckimi „planszami tytułowymi” do niektórych filmów. Najwyraźniej, mając przed sobą perspektywę dystrybuowania na obcym rynku, amerykańskie wytwórnie produkowały filmy sygnowane tytułami w zagranicznych językach. Brakuje, niestety, danych, aby generalizować na podstawie tego przypuszczenia. Ostatnim dziełem Griffitha w Biographie była Judyta $z$ Betulii (Judith of Bethulia, 1914), średniometrażowy dramat kostiumowy, zaprezentowany w Berlinie w kwietniu 1914 roku jako „największy triumf nowoczesnej sztuki filmowej”. Jednakże nazwisko reżysera nie było jeszcze wówczas marką, a więc nie zostało wymienione w reklamach prasowych. Dwa tytuły, które przyniosły sławę Griffithowi, Narodziny narodu (The Birth of a Nation, 1915) oraz Nietolerancja (Intolerance, 1916), nie doczekały się dystrybucji w Niemczech aż do 1924 roku, gdy nazwisko twórcy było już znane w pismach branżowych. Wojenny obraz Serca świata (Hearts of the World, 1918) rozpoczą wzmożoną dysputę, której głównym zagadnieniem była wątpliwość czy filmy Griffitha należy rozpatrywać $\mathrm{w}$ kategoriach sztuki, czy też propagandy.

Kulturowe znaczenie, jakie niosło za sobą w niemieckim kontekście kino amerykańskie, jest szczególnie widoczne w ilości zapożyczeń i przekształceń wątków westernu, rozciągających się od takich sfer kultury, jak „sztuka wysoka” aż po kulturowe „śmieci”. W dalszej części moich rozważań przedstawione zostaną przykłady różnych artystycznych, literackich, krytycznych i kinematograficznych odpowiedzi na ten amerykański gatunek.

Dla młodych artystów, obojętnych na niechęć okazywaną amerykańskim filmom przez Bildungsbürgertum ${ }^{* *}$, były one popularną rozrywką i służyły jako wehikuł umożliwiający przeniesienie się do Ameryki, krainy marzeń, której sami nigdy jeszcze nie widzieli. Malarz George Grosz, którego autobiografia stanowi żywy obraz epoki, był zupełnie niezainteresowany takimi kategoriami jak „,kultura” $\mathrm{i}$,śmieci”. Wspomina on:

Lepsze kinoteatry pokazywały głównie amerykańskie filmy. Jakże się śmialiśmy z zabawnego, grubego Johna Bunny'ego i jego dowcipów. Chociaż widzieliśmy również wiele francuskich filmów, na przykład te Pathé z Maxem Linderem i małym Fritzchenem Abélardem, żadne nie posiadały dramaturgicznego napięcia i nie odpowiadały lepiej naszym młodzieńczym fantazjom niż amerykańskie filmy tamtych czasów ${ }^{24}$.

24 George Grosz, Ein kleines Ja und ein großes Nein, Rewohlt: Reinbek bei Hamburg 1986 (pierwsza edycja 1955), s. 220 i nast. Tłumaczenie własne autorki. 
Dla Grosza i jego przyjaciół Ameryka była ekscytującą, wyimaginowaną przestrzenią, którą znali z powieści przygodowych swojego dzieciństwa - Grosz mając dziewięć lat podobno ręcznie przepisał cały tom Opowieści Skórzanej Pończochy Jamesa Fenimore’a Coopera - i którą teraz odnaleźli ożywioną w filmach. Przebierali się za miejskich kowbojów na studyjne przyjęcia, portretowali się w amerykańskim stylu czy nawet amerykanizowali swoje imiona. George Grosz, Rudolf Schlichter, Otto Dix oraz im współcześni przedstawiali amerykańskie sceny w swoich rysunkach i obrazach. W latach 1910-1925 Dziki Zachód budził szczególną fascynację wśród tej generacji, a elementy popularnego mitu starego pogranicza były przepuszczone przez nową soczewkę doświadczenia kinowego. Rudolf Schlichter, jak wzmiankował w swoich wspomnieniach, często szkicował podczas oglądania ${ }^{25}$. Ich obrazy, czerpiące ze świata powieści przygodowych i filmów, były fantazjami wyzwolenia i ucieczki z ciasnego i ograniczonego świata małomiasteczkowego wychowania, jak i od horroru wojny, do której Grosz, będąc dwa razy powołanym, a następnie zwolnionym, nie był entuzjastycznie nastawiony. Jednocześnie prace te urozmaicone były refleksją nad życiem w miejskiej dżungli. Zarysowane cechy brutalnych i szemranych indywiduów zaludniających typowe graniczne miasteczko były ugruntowane na doświadczeniu przemocy i zbrodni wojennej Europy, gdzie ulice, knajpy i kina wypełniali żołnierze i prostytutki. Swoją drogą, słowo „apasze” było powszechnym określeniem na miejskich przestępców i półprzestępców, które ujawnia, jak miejski półświatek i amerykański Zachód stapiały się w jedno w przestrzeni spragnionej przygód wyobraźni.

Amerykę George Grosz przedstawiał również w swojej poezji. Jego whitmanowski wiersz The Song of Golddiggers, opublikowany w 1917 roku na lamach Die Neue Jugend, jest doskonałym uzupełnieniem jego rysunku The Golddiger $(1916)^{26}$. Przytłaczające uczucie bycia otoczonym przez świat przemysłowej siły, która kumuluje się w „światowych konfliktach” i „wojnach” jest wyrażone w potoku pospiesznych, fragmentarycznych wykrzyknień. W tej futurystycznej wrzawie jest jednakże ukryta nuta archaicznej symboliki. Irracjonalne siły znoszą zracjonalizowany amerykański świat biznesu; inżynierowie zdają się być „czarnoksiężnikami w amerykańskich trzyczęściowych garniturach”. Co więcej, inżynier, paradygmatyczny dla industrialnego, racjonalnego świata, jest utożsamiony z poszukiwaczem złota. Współczesne ucieleśnienie kontroli i mocy jest zatem kojarzone z cechami preindustrialnego typu męskości spragnionej przygód. Tak jak i wiersz, również rysunek sytuuje figurę poszukiwacza złota, znaną z filmów i historii kowbojskich, we współczesnym, technicznym, miejskim krajobrazie. $\mathrm{Na}$ pierwszym planie widzimy śmiałego poszukiwacza w jednej dłoni trzymającego

25 Zob. Envisioning America, s. 23.

26 Zob. Hans Hess, George Grosz, Yale University Press: New Heaven-London 1985 , s. 62 i nast. 
łopatę, a w drugiej fajkę, przedstawionego na tle przestrzeni niezagospodarowanej, będącej nieużytkiem. Ze swoimi tatuażami, naszyjnikiem oraz pistoletem i nożem zatkniętymi za pasek, przypomina on marynarza. Za nim widoczna jest butelka likieru i strzykawka z morfiną - elementy stanowiące powiązanie z miejskim podziemiem przestępczym, na które transponowane jest doświadczenie pogranicza. Na drugim planie znajduje się port morski. W centrum rzędu budynków wyróżnia się napis „Kino”, wskazujący na źródło tych wyimaginowanych przygód.

Johan Huizinga w eseju Man and the Masses in America z 1918 roku był już świadom zawłaszczenia Zachodu przez kulturę masową oraz rosnącej wymiany handlowej między wolnym i otwartym Zachodem a cywilizowanym Wschodem. Przemysł związany z wypasem bydła na zachodnich preriach Mississippi, zwanych również państwem krów, zaczął się w 1860 roku. „W ciągu kilku lat kowboj przerodził się w typ, ze swoim własnym, nowiutkim romantyzmem, który wciąż żyje w filmach”. W ślad za wynalezieniem drutu kolczastego i ogrodzeń, „wolny wybieg bydła był stopniowo ograniczany przez proces grodzenia [...]. Kiedy pulkownik Cody - 'Buffalo Bill' - organizował swój Wild West Show w 1883 roku, był to już jedynie fragment kulturowej historii" ${ }^{27}$. Huizinga kontynuuje omawianie wielkich interesów zaangażowanych w przemysł hodowlany: pasterzy bydła na preriach, pakowaczy mięsa w Chicago, firm kolejowych oraz związku przedsiębiorców produkujących drut kolczasty. Fatalne warunki panujące w magazynach, w których pakowano mięso, były częstym obiektem krytyki, rozciągającej się na cały amerykański kapitalizm już od czasu powieści Uptona Sinclaira Grzęzawisko (The Jungle, 1906; niemieckie tłumaczenie ukazało się w tym samym roku). Barbarzyńska fabryka mięsa była w rzeczywistości drugą stroną romantyzowanych wolnych i nieskończonych prerii państwa krów. Choć życie w obu środowiskach na pierwszy rzut oka mogło wydawać się kompletnie różne, wzajemne powiązanie dzikości (wilderness) i cywilizacji, otwartej przestrzeni i zindustrializowanego miasta zaczynało kształtować się w świadomości intelektualistów i artystów początku dwudziestego stulecia.

Odkąd około 1830 roku przetłumaczono powieści Jamesa Fenimore’a Coopera, amerykańskie pogranicze stało się popularnym tematem $\mathrm{w}$ literaturze niemieckiej. Od lat 90. XIX wieku powieści Karola Maya, twórcy germańskiego superbohatera Old Shatterhanda i jego brata krwi Winnetou, szlachetnego Indianina, były wprost pochłaniane przez niemiecką młodzież. Ale to filmy obudzily nową fascynację amerykańskim Zachodem, zarówno w pisarzach, jak i malarzach pierwszego dziesięciolecia XX wieku. W poczytnym raporcie z podróży Amerika Heute und Morgen (1913), który miał znaczący wpływ na Franza Kafkę i innych

27 Johan Huizinga, America: A Dutch Historian's Vision, from Afar and Near, transl. Herbert H. Rowen, Harper \& Row: New York 1972, s. 12 i nast. 
pisarzy tamtych czasów, Arthur Holitscher opisał kręcenie filmów Vitagraphu w Kolorado. Został też uwieczniony na zdjęciu wraz z jednym z kowbojów ${ }^{28}$. Ekspresjonistyczni autorzy pisali kowbojskie nowele, wykazujące pokrewieństwo z filmowym rodzajem intryg i gestów. Na przykład Der Lazo Kasimira Edschmida (opublikowana w Die sechs Mündungen w 1915 roku) opowiada historię młodzieńczego buntu przeciwko majętnemu i uporządkowanemu życiu w mieście, które jako doświadczenia związane z prędkością, formę zabicia czasu i przerwę od nudy, oferuje jedynie jazdę konną i wyścigi samochodowe. Raoul Perten, apatyczny miejski młodzieniec, widzi statek parowy na plakacie i szybko wyrusza w podróż, by między pokładami przekroczyć Atlantyk. W czasie podróży wyzbywa się swoich starych nawyków, przybiera nowe gesty i nowy chód, by wzbudzać respekt w brutalnym, męskim świecie. Nie zatrzymuje się na długo w Nowym Jorku, lecz spieszy na zachód, gdzie zostaje kowbojem. Heroicznie opiera się powabom córki farmera i po pojedynku z niemieckim baronem, który jakimś cudem skończył na farmie, odjeżdża: dumny, samotny, wyprostowany. Postać osamotnionego kowboja zmierzającego w kierunku horyzontu wydaje się naśladować kompozycję obrazu filmowego.

Pierwsi ekranowi kowboje tacy jak Broncho Billy Anderson, Tom Mix i William S. Hart rozwinęli ikonografię bohatera Dzikiego Zachodu wraz z męskimi gestami i minami, które staną się powszechnie znajome dzięki licznym westernom wyprodukowanym w kolejnych dekadach. Jednakże we wczesnych westernach Davida Warka Griffitha akcja niekoniecznie była zogniskowana wokół postaci męskiego bohatera. Jego westerny często przedstawiały rodziny pionierów mozolnie posuwających się na zachód i napotykających niebezpieczeństwa, takie jak brak wody czy źli Indianie. W dramatach kolejowych (railroad dramas), takich jak Dziewczyna i powierzone jej dobro (The Girl and Her Trust, 1912), główne role mogły przypadać kobietom. Stopniowo jednak western rozwinął się w gatunek męski, w którym kobiety pojawiały się jako postacie podrzędne. To że we wczesnych westernach posiadały bardziej znaczącą pozycję, sugerowała również Emilie Altenloh, opisując cieszącą się powodzeniem formułę, którą powielały wczesne amerykańskie dramaty. Według Altenloh postacie kobiet bądź dziewcząt często pojawiały się w centrum akcji, broniąc drewnianej chatki przed wrogimi Indianami i nie poddając się, aż do przybycia ratunku w ostatniej chwili. Wraz z odsieczą pojawiał się też amant w typie „dobrego chłopca"29. Najwyraźniej więc western nie zawsze był zdominowany przez zadowolone z siebie męskie gwiazdy. Być może również legendarne „panny sklepowe” miały swoje miejsce we wczesnych dramatach kowbojskich.

28 Arthur Holitscher, Amerika Heute und Morgen, S. Fisher: Berlin 1913, s. 266-269.

29 Zob. E. Altenloh, Zur Soziologie des Kino..., s. 11 i nast. 
W retrospektywnym komentarzu Siegfrieda Kracauera poświęconym wczesnemu kinu niemieckiemu, Zachód jest w większym stopniu męską domeną. Według niego popularność amerykańskich ekranowych kowbojów wśród niemieckiej młodzieży i intelektualistów była skutkiem zaburzeń psychologicznych tych ostatnich:

Szczególnie dużym powodzeniem cieszyły się amerykańskie filmy cowboyskie. Broncho Bill i Tom Mix podbijali serca młodzieży niemieckiej, pochłaniającej tom za tomem powieści Karola Maya, których akcja obfitowała w niezwykłe wydarzenia, rozgrywające się na wyimaginowanym Dzikim Zachodzie z jego Indianami, krytymi furgonami, kupcami, myśliwymi, włóczęgami i awanturnikami. [...] Również wielu inteligentów cierpiących na brak jakiegoś celu w życiu chętnie uczęszczało na filmy cowboyskie, a to z uwagi na prosty sposób bycia, beztroski wygląd, ciągłą aktywność i bohaterskie wyczyny amerykańskich cowboyów filmowych. Żyjąca $\mathrm{w}$ stałej rozterce inteligencja akceptowała uproszczone sytuacje w westernach, życie, w którym bohater miał tylko jeden kierunek przed sobą $a^{30}$.

Ekranowi kowboje ze swoimi sformalizowanymi gestami mocy, kontroli i pewności siebie $w$ wyraźny sposób przemawiali do kompensacyjnych fantazji. Podczas gdy w prawdziwym życiu, we współczesnych industrialnych społeczeństwach, siła jednostki była coraz bardziej ograniczona, wyobraźnia znalazła ucieczkę w archaicznych cechach męskości. Front albo pogranicze były jedynymi miejscami, gdzie mężczyzna mógł jeszcze potwierdzić swoją siłę i męskość. Co znamienne, niemiecki ekspert w zakresie amerykańskiej filozofii, Eduard Baumgarten, przyrównywał swoje doświadczenie bycia młodym studentem na froncie I wojny światowej z doświadczaniem pogranicza przez Amerykanów. Podczas swojej drogi do sławy w latach 30. XX wieku wyraźnie chwalił „front” pierwszych osadników i ich męskie ideały ${ }^{31}$.

To co było wizualną przyjemnością dla jednych, dla drugich było cierniem. Podczas gdy filmy niosły za sobą wyzwalające impulsy dla chłopców w wieku szkolnym czy czeladników, marzących, aby wyrwać się spod surowej dyscypliny ich codziennego życia, szacowni i przyzwoici obywatele nie akceptowali westernowego szaleństwa, które opanowało młodzież. W kampanii przeciwko „śmieciom” religijny Ruch Reformowania Kina (Kinoreformbewegung) zaangażował się $\mathrm{w}$ ochronę kobiet i dzieci przed niekorzystnym zainteresowaniem i dekadenckim wpływem „obscenicznych” i „krwiożerczych” westernów czy filmów

${ }^{30}$ Siegfried Kracauer, Od Caligariego do Hitlera. Z psychologii filmu niemieckiego, tłum. Eugenia Skrzywanowa i Wanda Wertenstein, Filmowa Agencja Wydawnicza: Warszawa 1958, s. 22.

${ }^{31}$ Zob. Eduard Baumgarten, Amerikanische Philosophie und Deutscher Glaube, „Zeitschrift für französischen und englischen Unterricht" 1934, H. 33, s. 96-102. 
detektywistycznych. Twierdzono, że dzieciom na skutek oglądania brutalnych filmów grozi stępienie wrażliwości i kryminalizacja. Konrad Lange, profesor historii sztuki z Tybingi, był jednym z wielu żądających, by narodowe kino niemieckie pozostało wolne od obcych wpływów i niezepsute przez nie. Krytykował fakt, że właściciele kin nie brali na poważnie praw i regulacji zakazujących wpuszczania dzieci na filmy uznane przez cenzorów za szkodliwe. Jako przykład posłużyły Langemu pokazy Rote Rache: Farmerdrama in 5 Akten (Red Revenge, Farmer Drama in 5 Acts) w kinie w Tybindze. Najwyraźniej profesor był wystarczająco niepopularny, aby nie wpuszczono go do kina, a lokalna prasa odmówiła opublikowania jego propagandowego podjudzania. W swojej książce Das Kino in Gegewart und Zukunft zacytował zatem raport napisany przez swojego studenta:

Dzika Indianka z fantazyjną fryzurą, twarzą wykrzywioną w zwierzęcym grymasie, tajemniczo grasuje wokoło samotnego domu w górach. Nagle w wąskim przejściu pod nią pojawia się Bill (farmer), trzymając nerwowo broń w dłoni. Tam - napięcie osiąga szczyt, szalejąca muzyka smaga nerwy widzów - Pitjana chwyta ofiarę na dobrze wymierzone lasso i dusi ją z radością, gdy ta męczy się w bólach. W ostatniej minucie żona przybywa mu na ratunek. Pitjana znika tylko po to, by ponownie pojawić się po kilku minutach i zasztyletować żonę. Koniec aktu trzeciego. Sala kinowa zostaje oświetlona. Widzę kilkoro dzieciaków siedzących przede mną. Mała dziewczynka, około pięciu lat (!), walczy ze łzami, reszta pozostaje poważna. Wydaje się, że to głęboko wpłynęło na dusze dzieci. Być może była to pierwsza martwa osoba, jaką kiedykolwiek zobaczyły, i uwierzyły, że to wszystko było rzeczywiste... ${ }^{32}$

Już w 1911 roku wiele krajowych „dramatów z Dzikiego Zachodu” było reklamowanych takimi tytułami jak Der Pferdedieb lub Wild-West-Romantik. Choć żaden z nich się nie zachował, rzadkim przykładem kinowej recepcji tych klasycznych amerykańskich gatunków był Bull Arizona, der Wüstenadler (Bull Arizona, the Desert Eagle), wyprodukowany w Heidelbergu w 1919 roku. Równie dobrze możemy go jednak nazwać: „Dziki Zachód - made in Germany” albo „Jak niemiecki jest Heidelberg?”, albo „Jak amerykański jest western?”. Firma produkcyjna Chateau-Kunst-Film wyprodukowała całą serię Bull Arizona - filmów, z których najwyraźniej zachował się tylko jeden z sequeli, Das Vermächtnis der Prärie (The Legacy of the Praire) ${ }^{33}$. Chateau-Kunst-Film było małą, rodzinną firmą, która funkcjonowała w latach 1912-1925. Hermann Basler, wcielający się w postać tytułową serii, urodził się w Ludwigshafen w 1896 roku, przeją firmę po swoim

32 Konrad Lange, Das Kino in Gegenwart und Zukunft, Enke: Stuttgart 1920, s. 41.

33 Więcej filmograficznych informacji na temat obu filmów oraz uszczegółowione rozważania dotyczące niemieckiego przetwarzania westernów por. Denis Göktürk, Neckar-Western statt Donau-Walzer: Der Geschmack von Freiheit und Abenteuer im frühen Kino, „KINtop“ 1993, Nr. 2, s. 117-142. 
ojcu i zaczął pracę jako scenarzysta, reżyser i aktor zarazem. Jego matka również występowała w filmach, choćby w roli starszej damy w Bull Arizona, der Wüstenadler. Kino było popularną rozrywką nie tylko w metropoliach takich jak Berlin, ale również w prowincjonalnych miasteczkach, w których mieściły się także małe firmy produkcyjne, dziś zupełnie zapomniane, jednak niegdyś zaspokajające lokalne lub regionalne zapotrzebowanie ${ }^{34}$.

Trudno jednoznacznie stwierdzić, jaki zasięg miały te filmy, ponieważ właściwie nie przetrwały żadne informacje dotyczące liczby pokazów, widzów oraz składu widowni. Cenzorzy zabraniali dzieciom oglądania Bull Arizona, der Wüstenadler, ale nie wiemy, jak poważnie owe regulacje były traktowane i czy się do nich stosowano. Jedyny dokument, który pozwala nam założyć pozytywny odbiór filmu, to list napisany przez właściciela kina w Stuttgarcie, gdzie Bull Arizona, der Wüstenadler miał premierę 17 listopada 1919 roku za pośrednictwem firmy dystrybucyjnej Efes-Film. Właściciel kina wyraził zadowolenie z rekordowej popularności filmu i chciał przedłużyć pokazy o kolejny tydzień. W ciągu kolejnych tygodni zaaranżował również pokazy w pozostałych kinach, które posiadał w małych południowych miasteczkach, jak Ravensburg i Reutlingen ${ }^{35}$.

Bull Arizona, der Wüstenadler stanowi dobry przykład tego, jak konwencje amerykańskiego westernu były adaptowane w niemieckich remake'ach. Seria Bull Arizona w wyraźny sposób nawiązuje do wczesnych westernów z Williamem S. Hartem, jedną z pierwszych wielkich gwiazd tego gatunku. Hart rozpoczął swoją karierę kowboja w 1905 roku produkcją sceniczną The Squaw Man, następnie główną rolą w The Virginian. W swoich filmach był szczególnie znany jako podwójny rewolwerowiec (two-gun-man). Z kolei Hermann Basler, jako Bull Arizona, również przedstawiał się jako Zwei-Revolver-Mann. Co więcej, widoczne są również podobieństwa w sposobie gry aktorskiej, konstrukcji wątków i w tematyce. William S. Hart grywał też „nawróconych banitów”, twardzieli o miękkim sercu ukrytym pod twardą skorupą, którzy pod wpływem niewinnej i kulturalnej kobiety ze wschodniego wybrzeża daliby się przywrócić społeczeństwu ${ }^{36}$. Zakończenie Bull Arizona, der Wüstenadler jest celebracją męskiej samotności typowej

34 Standardowa filmografia niemieckiego kina niemego (Gerhard Lamprecht, Deutsche Stummfilme 1903-1931, 9 tomów i spis treści, Berlin 1970-1976) nie uwzględnia Bull Arizona, der Wüstenadler. Więcej informacji dotyczących wczesnej produkcji filmowej w Heidelbergu; por. Wolfgang Jacobsen, Das Glashaus am Neckar: Heidelberg und der Film, „epd Film“ 1985, Nr. 7, s. 15-19.

35 List został przedrukowany w celach reklamowych w dzienniku „Der Film” 1919, 23 November.

36 Więcej informacji poświęconych Williamowi S. Hartowi zob. Diane Kaiser Koszarski, The Complete Films of William S. Hart: A Pictorial Record, Dover Publications Inc.: New York, 1980. 
dla westernów. Po ocaleniu wędrującej grupy pionierów od śmierci z rąk Indian czy z pragnienia na pustyni, po walce z innym kowbojem $\mathrm{w}$ saloonie, nasz bohater przemierza niemieckie lasy. Spoglądając w dół na dolinę rozkłada ramiona: „Powraca do matki, która jako jedyna całkowicie go rozumie - do dzikości”.

Nie sposób ustalić, czy pierwsze westerny z Williamem S. Hartem były pokazywane w niemieckich kinach przed wojną, czy w jakiś sposób trafily do Niemiec w jej pierwszych latach. Wydaje się bardziej prawdopodobne, że aktor Hermann Basler, który stworzył postać tytułową serii Bull Arizona, widział filmy Harta podczas swojego pobytu w Ameryce w latach 1916-1918. Po powrocie prawdopodobnie dostrzegł dla siebie szansę wynikającą z niedostępności amerykańskich produkcji na niemieckim rynku, szybko przystąpił do filmowania ersatz-westernów i stworzył własną westernową gwiazdę. Ogólnoświatowe upodobanie do postaci „podwójnego rewolwerowca” jako modelu męskości chyba najlepiej wyraził Akira Kurosawa:

Filmy Williama S. Harta mają delikatny męski odcień (masculine touch), taki jak w późniejszych filmach Johna Forda [...]. W moim umyśle obraz pozostaje ozdobiony twarzą Williama S. Harta. W obu dłoniach trzyma pistolety, jego skórzane opaski na ramionach są przyozdobione złotem, na głowie zaś ma kapelusz z szerokim rondem i siedzi okrakiem na koniu. Albo jedzie przez ośnieżone lasy Alaski, mając na sobie futrzane ubranie i czapkę. To, co pozostaje w moim sercu $\mathrm{z}$ tych filmów, to niezawodny męski duch i zapach potu ${ }^{37}$.

Oczywiście sukces westernu oraz jego modelowe funkcje cech męskości nie były ograniczone jedynie do publiczności amerykańskiej. Jak zauważyliśmy, elementy westernu, a ponad wszystko postać kowboja, były chętnie przywłaszczane w Niemczech od wczesnych lat dwudziestego stulecia oraz przepracowywane w różnych mediach, takich jak malarstwo, film, literatura i krytyka kultury. Przytoczone przykłady pokazują, że przejawy westernowych tematów i motywów występowały zarówno w sztuce „wysokiej”, jak i tej „niskiej”, „śmieciowej”, a między różnymi mediami i sferami kultury istniały wzajemne relacje. Zarówno historia literatury, jak i sztuki ograniczone do ustalonego kanonu, zdawały się o tym zapominać. Skupienie uwagi raczej na społecznej funkcji wytworów kultury i konkretnym historycznym momencie niż na kwestii ich estetycznej oceny potwierdza, że granica między kulturą masową a wysoką jest w istocie raczej nieszczelna.

Po wprowadzeniu nowego kontekstu symbole kulturowe często obarczane są nowym znaczeniem. W Stanach Zjednoczonych, gdy Zachód został już zromantyzowany przez ludzi ze Wschodu, takich jak Owen Wister, Frederic Remington czy Theodore Roosevelt, szorstcy, lecz uczciwi i męscy, całkiem zgodni z rządo-

${ }^{37}$ Akira Kurosawa, Something like an Autobiography, Vintage Books: New York 1983, s. 39. 
wą polityką, ekranowi kowboje pokroju Williama S. Harta mogli stać po stronie „dobrych”, amerykańskich wartości. Jednak grupy, które przejęły kowbojów w Niemczech, były często mniej tradycyjne i patriotyczne. Podczas gdy konserwatywni krytycy byli głęboko zatroskani ,amerykanizacją” i rewolucją hierarchii kulturowych spowodowanymi nowymi formami masowej rozrywki, artyści tacy jak George Grosz czy ekspresjonistyczni pisarze jak Kasimir Edschmid, pod wieloma względami reprezentujący młodzież wilhelmińskich Niemiec i lubujący się w filmach, stwarzali w wyobraźni Amerykę jako przestrzeń wolności i przygód. Dla nich kowboj był popularnym emblematem młodzieńczego buntu. A więc pytanie, jakie z tego wynika, brzmi: jak bardzo nowoczesny jest kowboj?

$\mathrm{Z}$ angielskiego przełożyli Adam Cybulski i Monika Rawska

Przypisy thumacza i redakcji

Wiele źródeł internetowych, w tym Internet Movie Database, podaje inną datę urodzin aktora: 21 marca 1880 r. (przyp. tłum.).

** Niemiecki termin oznaczający zamożne i wykształcone mieszczaństwo (przyp. red.). 